\title{
BOTTOM DEPOSITS OF STRATIFIED, SEEPAGE, URBAN LAKE (ON THE EXAMPLE OF TYRSKO LAKE, POLAND) AS A FACTOR POTENTIALLY SHAPING LAKE WATER QUALITY
}

\author{
Renata Augustyniak ${ }^{1 *}$, Maciej Neugebauer ${ }^{2}$, Joanna Kowalska ${ }^{1}$, Daniel Szymański', \\ Grzegorz Wiśniewski' , Zofia Filipkowska ${ }^{3}$, Jolanta Grochowska', Michał Łopata', \\ Katarzyna Parszuto ${ }^{1}$, Renata Tandyrak ${ }^{1}$
}

1 Department of Water Protection Engineering, University of Warmia and Mazury in Olsztyn, Prawocheńskiego St. 1, 10-720 Olsztyn, Poland

2 Department of Electrical Engineering, Power Engineering, Electronics and Automation, University of Warmia and Mazury in Olsztyn, Prawocheńskiego St. 1, 10-720 Olsztyn, Poland

3 Department of Environmental Microbiology, University of Warmia and Mazury in Olsztyn, Prawocheńskiego St. 1, 10-720 Olsztyn, Poland

* Corresponding author's e-mail: rbrzoza@uwm.edu.pl

Received: 2017.05.05

Accepted: 2017.08.01

Published: 2017.09.01

\begin{abstract}
The object of the study was Tyrsko Lake (area 18.6 ha, max. depth $30.4 \mathrm{~m}$ ), located in the western part of Olsztyn (Olsztyn Lakeland). This lake is one of the clear water lakes in Olsztyn, but the progressive deterioration of water quality has been observed during recent years. The phosphorus concentration in the water-sediment interface, phosphorus fractions quantity and the amount of components which can bind this element was investigated in the upper $(0-5 \mathrm{~cm})$ layer of deposits. The aim of study was to analyze the potential influence of bottom sediment on the lake water quality. The obtained results revealed that the bottom sediment of Tyrsko Lake can be classified as mixed, silica-organic type, with a relatively high content of iron (over $4 \% \mathrm{Fe}$ in d.w.). The total phosphorus content was ca. $3.5 \mathrm{mg} \mathrm{P} \mathrm{g}^{-1} \mathrm{~d}$.w. on average. Phosphorus in the bottom sediment was bound mainly with organic matter ( $\mathrm{NaOH}$-nrP fraction), which had over $50 \%$ share in TP. Highly mobile fractions $\left(\mathrm{NH}_{4}-\mathrm{Cl}-\mathrm{P}\right.$ and BD-P) together only included ca. 5\% to 7\% TP. The obtained results show that the bottom sediment of Tyrsko Lake can bind phosphorus quite effectively. The calculated internal mineral phosphorus loading during summer stagnation period was $10.9 \mathrm{~kg}$ and it was lower that the assessed annual external phosphorus load $(22.6 \mathrm{~kg})$. The assessed annual phosphorus loading from both sources was still lower than the critical load according to Vollenweider criteria. However, due to the fact that the internal loading phenomenon is occurring in the lake, it should be taken into consideration that the lake water quality can deteriorate gradually during the longer time perspective. These findings should be accounted for in the future if the potential protection and restoration procedures will be developed.
\end{abstract}

Keywords: urban lake, phosphorus, bottom sediment, internal loading

\section{INTRODUCTION}

The urban lakes constitute a very valuable part of landscape. Unfortunately, the direct human activity in their drainage basins can result in the deterioration of water quality. The location of human settlements in the direct catchment, forests cutting, using land for intensive agriculture can cause a higher risk of pollutants loading to freshwater ecosystems [Brzozowska et al. 2013, Gonsiorczyk et al. 1997, van Hullebush et al 2003]. 
The autochthonous and allochthonous matter (including the products of physical, chemical and biological processes, which take place in the lake and its catchment, as well as pollutants) is ultimately stored in the bottom zone of lakes. The chemical composition of lake sediment is the result of various processes taking place during deposit forming and subsequent diagenesis [Borówka 2007, Łukawska-Matuszewska et al. 2013]. The bottom deposit is a very important part of lacustrine ecosystem. The exchange processes of chemical compounds in the sedimentwater interface are mainly directed towards the sediment phase, when the redox potential value in the near-bottom water is high. With the decrease of redox potential caused by oxygen depletion in the bottom water zone (which is characteristic for eutrophic lakes), the compounds stored in sediment can be mobilized and returned to lake water [Søndergaard et al. 2001].

Numerous studies emphasize the phosphorus compounds loading role in a shaping the lake water quality [e.g. Gonsiorczyk et al. 1997, van Hullebush et al 2003, Jensen et al. 1992, Søndergaard et al. 2001]. Apart from an assessment of the external loading of phosphorus compounds, which are widely known as the key factor for eutrophication, an essential element required for the prediction of potential changes in lake water quality is the information about the phosphorus stored in the upper part of bottom deposits. Total phosphorus content in sediment can be used as a good predictor for potential eutrophication rate in a lake. However, due to the fact that phosphorus can create bonds with different sediment components, which differ in a solubility, the analysis of phosphorus fractions amounts provides much more precise information about a potential sediment influence on lake water quality [Kentzer 2001, van Hullebush et al. 2003]. The most mobile phosphorus pool, which is present in the sediment phase as the phosphates in the interstitial water, can directly diffuse into near-bottom water [Gonsiorczyk et al. 1997].

Due to the fact, that bottom deposits can include more than $90 \%$ of the total phosphorus amount in the whole lake ecosystem, they can be a serious threat for the lake water quality if the internal loading phenomenon will occur [Kajak 2001, Kentzer 2001, Pei Sun Loh et al. 2013]. Hence, due to the phenomenon of phosphorus internal loading in a lake, the trophic state of a lake is threatened by accelerated eutrophication. According to Vollenweider [1968] and Bajkiewicz-Grabowska [2002] the seepage lakes are more susceptible to degradation comparing to lakes, which have surface outflow. Then, an analysis of chemistry of bottom sediment in a lake, with the emphasis on phosphorus, is the necessary condition for any urban lake, and should be taken into consideration in water quality management and planning.

The aim of the presented study was to analyze the potential influence of bottom sediment on the urban seepage lake water quality.

\section{MATERIALS AND METHODS}

The research was conducted on Tyrsko Lake (area 18.6 ha, max depth $30.4 \mathrm{~m}$ ), located in the western part of Olsztyn city (Olsztyn Lakeland) (Fig. 1). This water body has no surface outflows and inflows (seepage lake). This lake wa-

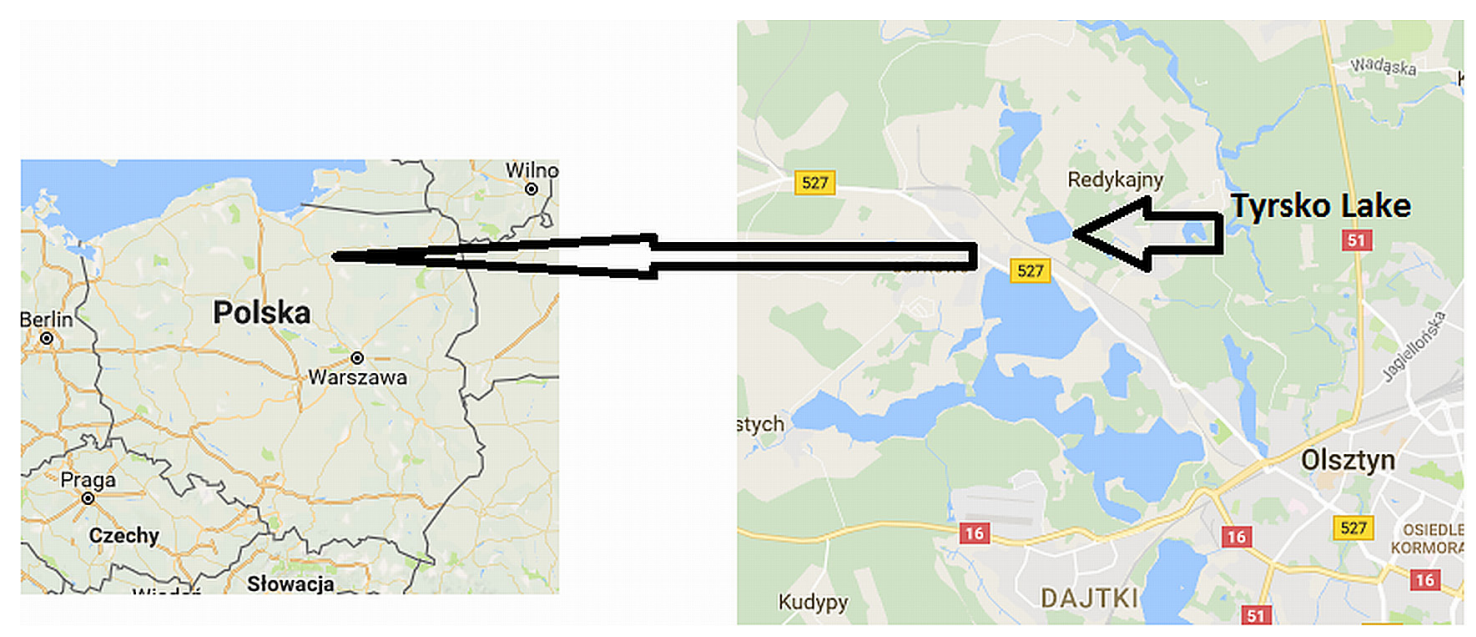

Fig. 1. Location of Tyrsko Lake (www.google.pl/maps) 
ter mixing type is bradimictic. After a period of spring circulation a cold hypolimnetic zone is developed, which is isolated from epilimnion by a thermocline with a high temperature gradient $\left(5^{\circ} \mathrm{C} \mathrm{m}^{-1}\right.$ above) [Lossow et al. 2005]. The basic morphometric data and the direct drainage basin development are shown in the Tables 1 and 2.

The thermal and oxygen profiles were measured using ProOdo probe (YSI).

The samples of near-bottom water and bottom sediments were taken using Kajak bottom sampler at one station, located on the deepest point of lake (30.4 m) (Fig. 2).

The near bottom water was obtained after decantation of $10-\mathrm{cm}$ thick water layer above the taken, undisturbed sediment cores. The upper sediment layer $(0-5 \mathrm{~cm})$ was taken for analysis. The interstitial water was obtained after centrifugation (MPW-32 centrifuge, $3000 \mathrm{rpm}, \mathrm{t}=20$ min). The water analyses included: phosphorus forms, iron and manganese with method according to Hermanowicz et al. [1999]. The sediment analysis included: organic matter, iron, aluminum, calcium - according to the method proposed by Januszkiewicz [1978], total carbon (by IL 550 TOC-TN analyzer, Hach Inc.), phosphorus fractions - according to method described by van Hullebush et al. [2003]. The Merck SQ118 and Macherey Nagel's Nanocolor spectrophotometers

Table 1. Basic morphometric data of Tyrsko Lake [by Lossow et al. 2005]

\begin{tabular}{|l|c|}
\hline \multicolumn{1}{|c|}{ Characteristics } & Value \\
\hline Area & $18.6 \mathrm{ha}$ \\
\hline Maximum depth & $30.4 \mathrm{~m}$ \\
\hline Mean depth & $6.6 \mathrm{~m}$ \\
\hline Relative depth index & 0.070 \\
\hline Depth index & 0.032 \\
\hline Volume & $1786.1 \cdot 10^{3} \mathrm{~m}^{3}$ \\
\hline Shoreline lenght & $1,620 \mathrm{~m}$ \\
\hline Shoreline development index & 1.10 \\
\hline
\end{tabular}

Table 2. Drainage basin management of Tyrsko Lake [by Lossow et al. 2005]

\begin{tabular}{|l|c|}
\hline \multicolumn{1}{|c|}{ Land use } & Area [ha] \\
\hline Forests & 24.7 \\
\hline Barren lands & 28.6 \\
\hline Urban area & 7.6 \\
\hline Swamps & 6.2 \\
\hline Recreational area and orchards & 1.1 \\
\hline Total & 68.2 \\
\hline
\end{tabular}

were used for the analyses. The mineral phosphorus load from the bottom sediment to near-bottom water was calculated on the basis of equations done in paper by Gonsiorczyk et al. [1997]:

$$
J=\phi D s \frac{d C}{d x}
$$

where: $J$ - the mineral phosphorus load passing from sediment into water $\left[\mathrm{mg} \mathrm{P} \mathrm{m}^{-2} \mathrm{~d}^{-1}\right]$

Ds - diffusion coefficient in the sediment $\left[\mathrm{m} \mathrm{d}^{-1}\right]$

$\Phi$ - porosity $\left[\mathrm{m}^{3}\right.$ interstitial water $\mathrm{m}^{-3}$ wet sediment]

$d C$ - mineral phosphorus concentration difference $\left[\mathrm{mg} \mathrm{m}^{-3}\right.$ ]

$d x$ - diffusion distance $[\mathrm{m}]$

According to Clavero et al. [1992]:

$D s=\mathrm{Di} \phi / \mathrm{F}$, where:

Di - molar diffusion coefficient - for $\mathrm{H}_{2} \mathrm{PO}_{4}$ at $5^{\circ} \mathrm{C}\left(4.0810^{-5} \mathrm{~m}^{2} \mathrm{~d}^{-1}\right)[\mathrm{Li}$ and Gregory 1974]

$F=1.28 / \phi^{2}$

The main assumption of phosphorus internal loading calculation was that the bradimictic lake hypolimnion is totally isolated from the upper lake water strata during the summer stagnation period. Then, the increase in mineral phosphorus concentration in the near-bottom water is the result of the processes which have taken place in the water-sediment interface, mainly as diffusion, enhanced by bioturbation, gas $\left(\mathrm{CH}_{4}, \mathrm{~N}_{2}, \mathrm{CO}_{2}\right)$ production in sediment etc.

The following properties were assessed: the mineral phosphorus load released from bottom sediment, daily mineral phosphorus exchange rates during summer stagnation period and the phosphorus internal loading, as an analogy to the phosphorus loads calculated according to Vollenweider criteria [1968].

\section{RESULTS}

The thermal and oxygen profiles of Tyrsko Lake which were made during research prove that lake suffers from the summer hypolimnetic anoxia. The summer oxygen curve is a typical clinograde, showing oxygen depletion below $21 \mathrm{~m}$ of depth (Fig. 3).

The analyzed components concentration ( $\mathrm{Fe}, \mathrm{Mn}, \mathrm{P}$ min and TP) in the investigated water strata were several times higher in the inter- 


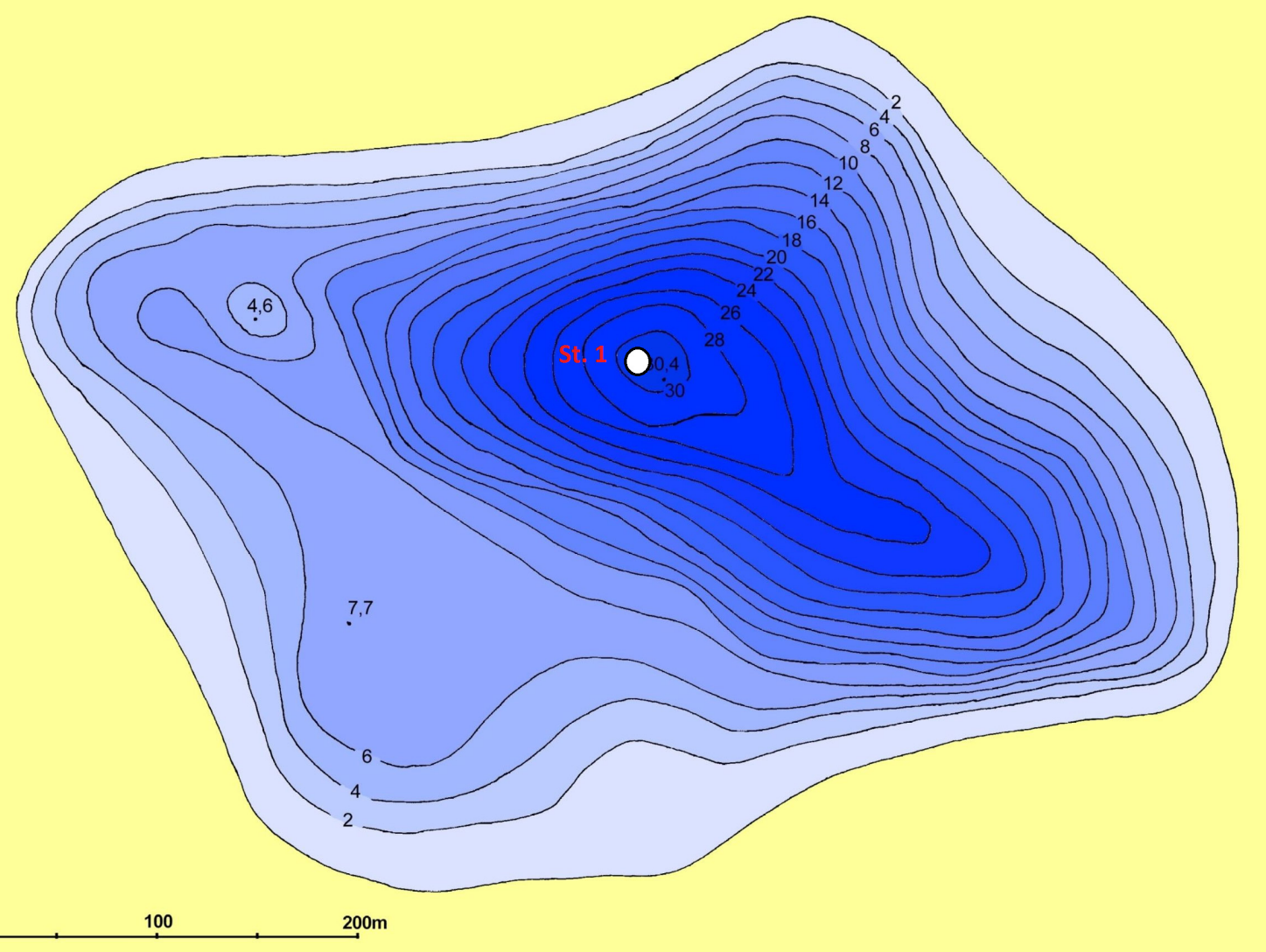

Fig. 2. Bathymetric plan of Tyrsko Lake with a sampling station location (Department of Water Protection Engineering 1992)
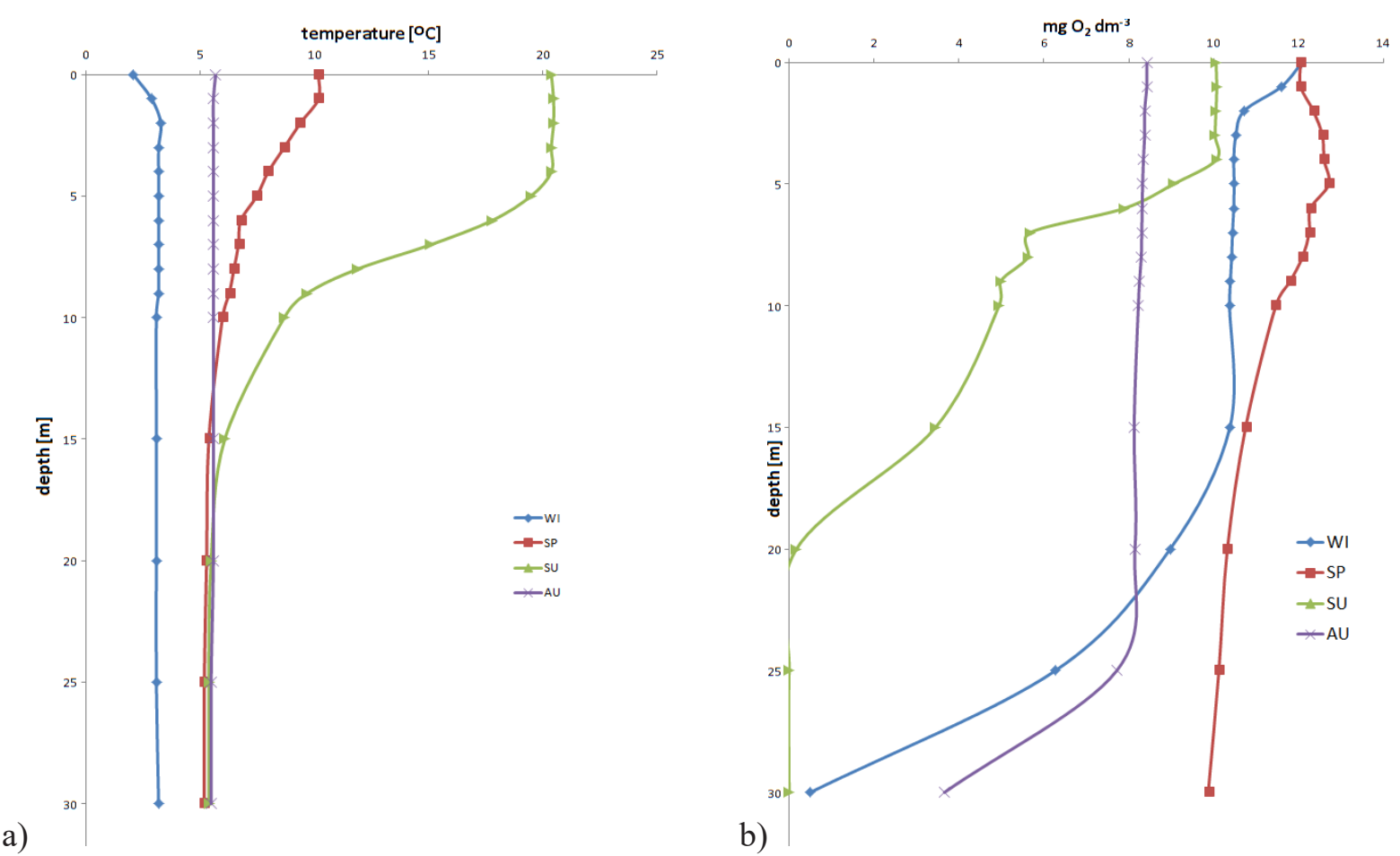

b)

Fig. 3. Seasonal thermal (a) and oxygen (b) profiles in the Tyrsko Lake water 
stitial water, comparing to near-bottom water. The maximum phosphorus compounds amounts (TP $-2.252 \pm 0.114 \mathrm{mg} \mathrm{P} \cdot \mathrm{dm}^{-3}$ and P min -1.919 $\pm 0.105 \mathrm{mg} \mathrm{P} \cdot \mathrm{dm}^{-3}$ ), as well as the highest iron and manganese concentration $\left(13.9 \mathrm{mg} \mathrm{Fe} \cdot \mathrm{dm}^{-3}\right.$ and $6.8 \mathrm{mg} \mathrm{Mn} \cdot \mathrm{dm}^{-3}$ ) were noted in the interstitial water during summer season. The Fe and $\mathrm{Mn}$ concentration changes (during research period) were positively correlated with $\mathrm{P}$ min concentration changes (for $\mathrm{Fe}-\mathrm{r}=0.959, \mathrm{n}=8, \mathrm{p}<0.01$ and for $\mathrm{Mn}-\mathrm{r}=0.960, \mathrm{n}=8, \mathrm{p}<0.01)$. The seasonal changes in the mineral and total phosphorus concentration as well as iron and manganese amounts in the near-bottom and interstitial water layers are shown in Figure 4.

The bottom sediment of Tyrsko Lake can be classified as mixed, silica-organic type. Both organic matter and silica contents did not exceed $50 \%$ of d.w. The iron and aluminum amounts were higher than calcium amounts.
The average total phosphorus level in the bottom sediment amounted to $3.45 \mathrm{mg} \mathrm{P} \mathrm{g}^{-1} \mathrm{~d}$.w. The main pool of that element in the bottom sediment of Tyrsko Lake was bound with organic matter (as $\mathrm{NaOH}$-nrP fraction) (2.257 $\mathrm{mg} \mathrm{P} \mathrm{g}^{-1}$ d.w. on average - more than $50 \% \mathrm{TP}$ ). The second (res- P) fraction amount was $0.543 \mathrm{mg} \mathrm{P} \mathrm{g}^{-1}$ d.w. on average (over $15 \% \mathrm{TP})$. $\mathrm{T}$ the third (NaOH-rP) fraction share in $\mathrm{TP}$ was almost $11 \%\left(0.373 \mathrm{mg} \mathrm{P} \mathrm{g}^{-1}\right)$. The most mobile fractions $\left(\mathrm{NH}_{4} \mathrm{Cl}-\mathrm{P}\right.$ and $\left.\mathrm{BD}-\mathrm{P}\right)$ contents were the lowest $\left(0.036 \mathrm{mg} \mathrm{P} \mathrm{g}^{-1}\right.$ d.w. and $0.185 \mathrm{mg} \mathrm{P} \mathrm{g}^{-1}$ d.w. on average, respectively). The structure of phosphorus fractions in the bottom sediment of Tyrsko Lake during different seasons is shown in Figure 5.

The calculated internal mineral phosphorus loading during summer stagnation amounted to $10.85 \mathrm{~kg}$ and was lower than the external P loading assessed by Lossow et al. [2005] $-22.6 \mathrm{~kg}$. The values of external and internal $\mathrm{P}$ loading for Tyrsko Lake are shown in Table 4.

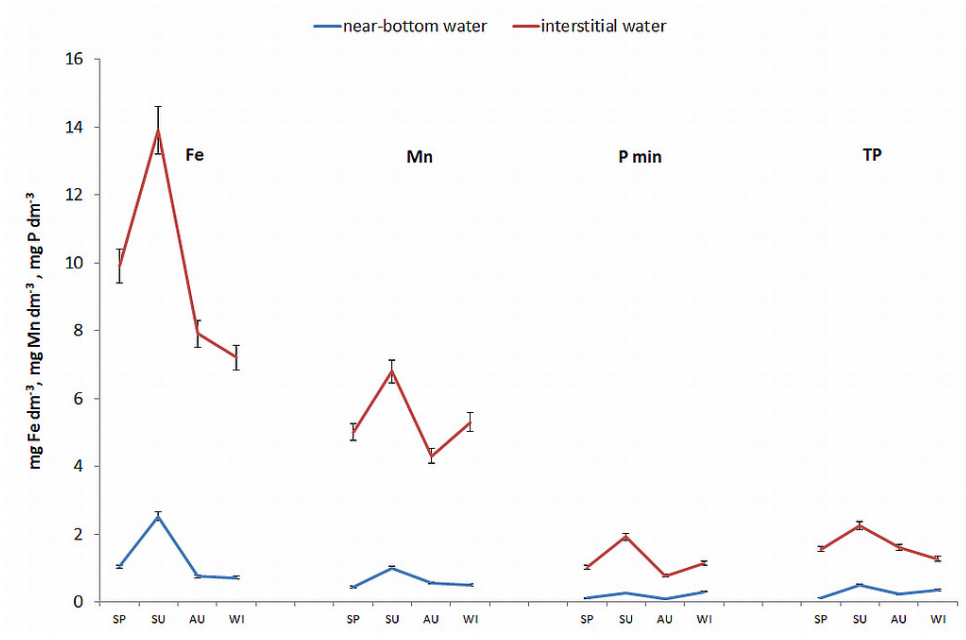

Fig. 4. Seasonal changes in the iron, manganese, mineral and total phosphorus concentration in the near-bottom and interstitial water layers

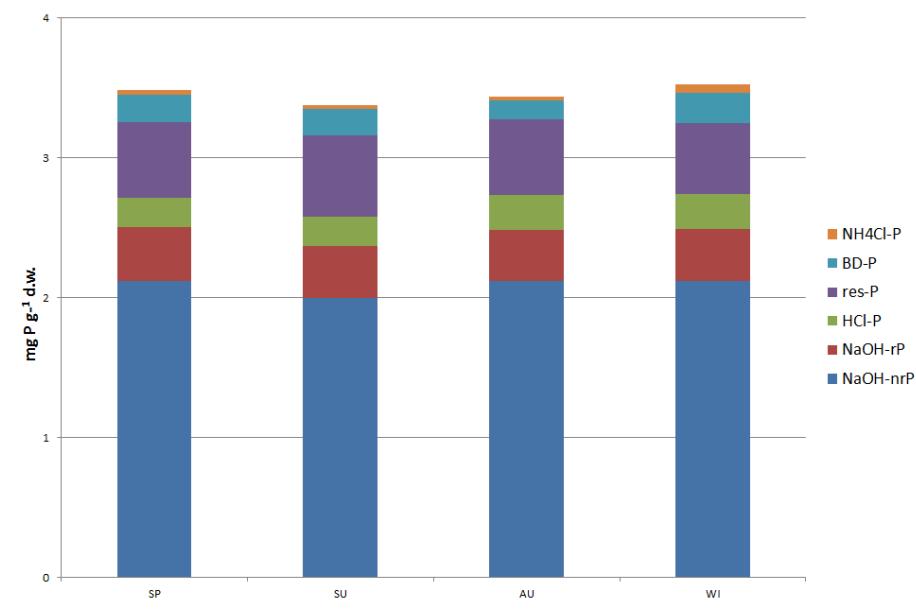

Fig. 5. Seasonal changes in phosphorus fractions in the bottom sediment of Tyrsko Lake 


\section{DISCUSSION}

The Tyrsko Lake, similarly to Redykajny Lake located nearby, was a water body with the least advanced eutrophy among all the lakes located in the area of Olsztyn city [Lossow et al. 2005]. Until 1980s, the lake constituted a habitat of the relict plant Isoetes lacustris L. [Chudyba et al. 1987], and because of that fact it was protected nature reserve since 1957 until 1987. However, the increased human activity in the direct drainage basin area during the last decades (location of intensive horticulture objects without sewerage infrastructure, building of a hotel complex, increasing recreational pressure and an expansion of urban areas) has caused the progressing eutrophication [Lossow et al. 2005].

One of the main symptoms of the developing eutrophication of lacustrine ecosystems is the presence of hypolimnetic anoxia. The organic matter deposited in the bottom sediment has depleted oxygen for decay processes and it led to progressive anoxia in the hypolimnion. The profundal bottom sediment of Tyrsko Lake was

Table 3. The selected components mean contents in the bottom sediment of Tyrsko Lake

\begin{tabular}{|l|c|}
\hline \multicolumn{1}{|c|}{ Component } & $\begin{array}{c}\text { Mean content } \\
\left(\mathrm{mg} \mathrm{g}^{-1} \mathrm{~d} . \mathrm{w} . \pm \mathrm{SD}\right)\end{array}$ \\
\hline Organic matter & $379.62 \pm 23.565$ \\
\hline $\mathrm{Fe}$ & $43.76 \pm 2.452$ \\
\hline $\mathrm{Al}$ & $23.32 \pm 0.803$ \\
\hline $\mathrm{Ca}$ & $10.86 \pm 1.079$ \\
\hline $\mathrm{Mn}$ & $1.61 \pm 0.201$ \\
\hline $\mathrm{TN}$ & $23.21 \pm 2.357$ \\
\hline $\mathrm{TC}^{\mathrm{SiO}}$ & $242.35 \pm 9.116$ \\
\hline
\end{tabular}

Table 4. Calculated loads of mineral phosphorus released from the bottom sediment during summer stagnation period in Tyrsko Lake (assessed in present research), comparing to the external P loading (with asterisk* - according to Lossow et al. 2005)

\begin{tabular}{|c|c|}
\hline Phosphorus loads and fluxes & Value \\
\hline $\begin{array}{l}P_{\min } \text { load released from sediment during } \\
\text { summer season }[\mathrm{kg}]\end{array}$ & 10.85 \\
\hline Daily $\mathrm{P}_{\min }$ flux [mg $\left.\mathrm{P} \mathrm{m}^{-2} \mathrm{~d}\right]$ & 1.09 \\
\hline Internal $\mathrm{P}$ loading [g $\mathrm{P} \mathrm{m}^{-2}$ year] & 0.058 \\
\hline $\begin{array}{l}\text { Critical P loading assessed according to } \\
\text { Vollenweider [1968] } \\
\text { [g P } \mathrm{m}^{-2} \text { year] }\end{array}$ & 0.20 \\
\hline $\begin{array}{l}\text { External TP loads from catchment and } \\
\text { atmosphere }{ }^{*}[\mathrm{~kg}]\end{array}$ & 22.6 \\
\hline External $\mathrm{P}$ loading* [g P $\mathrm{m}^{-2}$ year] & 0.12 \\
\hline
\end{tabular}

rich in the organic matter - the noted amounts of this component exceeded $370 \mathrm{mg} \mathrm{g}^{-1} \mathrm{~d}$.w. (Table 3). Similar organic matter level was frequently noted in the stratified eutrophic lakes (Brzozowska et al. 2013, Kentzer 2001) The TC:TN ratio for Tyrsko Lake profundal sediment was in the range between 9.7 and 11.6, which suggests its phycogenic origin from water-column production (Koszelnik 2009, Mahapatra et al. 2011, Meyers and Ishiwatari 1993, Mielnik et al. 2009). Organic matter was also the main component binding the phosphorus in the bottom sediment of Tyrsko Lake - NaOH-nrP quantitatively dominated among different phosphorus fractions in the studied sediment. According to the research performed by e.g. Kentzer [2001] that sediment component plays the main role in phosphorus binding in bottom deposits of numerous lakes. NaOH-nrP fraction is known as the moderately mobile $\mathrm{P}$ fraction (Psenner et al. 1988). Because of the anoxic conditions and low water temperature in the profundal water-sediment interface, the organic matter mineralization processes are much slower than in the shallow "active bottom" zone. More mobile $\mathrm{P}$ fractions in these conditions are $\mathrm{NH}_{4} \mathrm{Cl}-\mathrm{P}$ (P loosely sorbed onto sediment particles) and BD-P (P sensitive on redox potential changes, mainly connected with Fe compounds) [Kentzer 2001, Psenner et al. 1988, van Hullebush et al. 2003]. The share of both fractions in the total phosphorus of Tyrsko Lake profundal sediment was not high and amounted to ca. $6 \%$ TP. Hardly mobile fraction (HCl-P) and practically non-mobile fraction (res-P) occupied together ca. 20\% TP. The obtained results revealed that the bottom sediment of Tyrsko Lake can bind phosphorus quite effectively - the majority of phosphorus in sediment was stored in less mobile fractions.

Anaerobic conditions in the hypolimnetic bottom zone of Tyrsko Lake during a stagnation period have caused the mineral phosphorus release from sediment. The observed increase in the concentration of these elements in the both analyzed water strata (near-bottom and interstitial water) and a positive correlation between $\mathrm{Fe}$ and Mn amounts as well as mineral phosphorus concentration, confirmed the presence of the internal loading phenomenon. It can constitute a serious source of phosphorus in lakes [Kajak 2001, Klapper 2003, Pei Sun Loh et al. 2013, van Hullebush et al. 2013]. However, the calculated values of the daily flux of phos- 
phates for Tyrsko Lake can be characterized as lower than the values found for eutrophic lakes [Brzozowska et al. 2001, Søndergaard et al. 2001]. The estimated internal P load (10.85 $\mathrm{kg} \mathrm{P}$ ), released from the sediment during the summer stagnation was lower than the P loads from external sources assessed by Lossow et al. [2005] and it amounted to ca. 50\% of external phosphorus loading $(22.6 \mathrm{~kg})$. Even the total P load from internal and external sources did not exceed the critical load calculated according to Vollenweider [1968] (Table 4). It can be possible that the high ratio of Fe:P in the water-sediment interface of this lake (over 3 in the near-bottom water and greater than 10 in the interstitial water) can influence the lesser $P$ internal loading. In such case, maintaining of oxic condition in the bottom zone is crucial for $\mathrm{P}$ binding [Jensen et al. 1992, Klapper 2003].

\section{CONCLUSIONS}

The impact of the bottom sediment on the water quality of Tyrsko Lake assessed on the basis of the presented research results does not seem to be strong. It indicates that there is a little risk of rapid acceleration of the lake eutrophication process at the present time. However, due to the fact that the internal loading phenomenon is occurring in the lake, the water quality can deteriorate gradually during the longer time perspective. Hence, while considering the way of maintaining good water quality in Tyrsko Lake, the two conditions should be met. Firstly, it is necessary to mitigate the external $\mathrm{P}$ loading by limitation of pollution from non-point sources. Moreover, the sewerage system failures with sewage leaks, which were even described in the local press in the recent years, seem to be a real threat for Tyrsko Lake water quality and it must be eliminated. Secondly, because the phosphorus internal loading occurs in the lake, it will be necessary to implement the best technical method for limiting that phenomenon. Tyrsko Lake sediment is rich in the iron compounds; therefore, the improvement of oxic condition in the hypolimnion should be taken into consideration. According to the pieces of advice presented by Klapper [2003] and Lossow and Gawrońska [2000] the artificial aeration without destratification (hypolimnetic aeration) seems to be the best solution in this case.

\section{Acknowledgements}

The research was financed by National Science Center basing on decision No DEC-2011/01/B/ST10/06569.

\section{REFERENCES}

1. Bajkiewicz-Grabowska E. 2002. Circulation of matter in the river-lake systems (in Polish). Warszawa 2002.

2. Borówka R.K. 2007. Geochemical analysis of bottom sediments of moderate zone lakes (in Polish). Studia Limnologica et Telmatologica 1(1), 33-42.

3. Brzozowska R., Gawrońska H., Grochowska J., Lossow K. 2001. Nutrient release from the bottom sediments of artificially aerated Lake Długie. Limnological Review 1, 25-32.

4. Brzozowska R., Wiśniewski G., Dunalska J., Filipkowska Z., 2013. Sediment phosphorus fractions in an urban lake and its usability for predicting of the internal loading phenomenon. International Journal of Environment and Health, 6(4), 340-349.

5. Chudyba H., Chudyba D., Endler Z. 1987. Vegetation of the Tyrsko Lake floristic reserve (in Polish). Acta Acad. Agricult. Tech. Olst., Protectio Aquarum et Piscatoria, 17, 45-88.

6. Gonsiorczyk T., Casper P., Koschel R. 1997. Variation of phosphorus release from sediments in stratified lakes. Water, Air and Soil Pollution 99, 427-434.

7. Hermanowicz W., Dojlido J., Dożańska W., Koziorowski B., Zerbe J. 1999. Physical and chemical analysis of water and sewage (in Polish). Arkady. Warszawa.

8. Kentzer A. 2001. Phosphorus and its biologically available fractions in the bottom sediments of lakes with different trophic status (in Polish). UMK, Toruń 2001.

9. van Hullebush E., Auvray F., Deluchat V., Chazal P., Baudu M. 2003. Phosphorus fractionation and short-term mobility in the surface sediment of a polymictic shallow lake treated with a low dose of alum (Courtille Lake, France). Water, Air and Soil Pollution 146, 75-91.

10. Januszkiewicz T., 1978. Studies on the analysis method of recent bottom sediments of lakes (in Polish). Zesz. Nauk. ART. Olsztyn, 187(8), 3 - 30.

11. Jensen, H.S., Kristensen, P., Jeppesen, E., Skytthe A. 1992. Iron:phosphorus ratio in surface sediment as an indicator of phosphate release from aerobic sediments in shallow lakes. Hydrobiologia 235, $731-743$.

12. Kajak Z. 2001. Hydrobiology-limnology. Freshwater ecosystems (in Polish). PWN Warszawa 
13. Klapper H. 2003. Technologies for lake restoration. J. Limnol. 62(Suppl. 1),73-90.

14. Koszelnik P. 2009. Sources and distribution of nutrients as exemplified by the Solina-Myczkowice Reservoir Complex case study (in Polish). Oficyna Wydawnicza Politechniki Rzeszowskiej, Rzeszów 2009.

15. Lossow K., Gawrońska H. 2000. Water reservoirs protection. The review of lake restoration methods (in Polish). Przegląd Komunalny 9(108), 92-106.

16. Lossow K., Gawrońska H., Mientki C., Wiśniewski G., Łopata M., 2005. Lakes of Olsztyn. Trophic state, threats (in Polish). Edycja S.C., Olsztyn 2005

17. Łukawska-Matuszewska K., Vogt R.D., Xie R. 2013. Phosphorus pools and internal loading in a eutrophic lake with gradients in sediment geochemistry created by land use in the watershed. Hydrobiologia 713, 183-197.

18. Mahapatra D.M, Chanakaya H.N., Ramachandra T.V. 2011. C:N ratio of sediments in a sewage fed urban lake. International Journal of Geology, 3(5), 86-92.

19. Meyers P.A., Ishiwatari R. 1993. Lacustrine organic geochemistry - an overview of indicators of organic matter sources and diagenesis in lake sediments. Org. Geochem. 20(7), 867-900.

20. Mielnik L., Piotrowicz R., Klimaszyk P. 2009. Chemical properties of bottom sediments in throughflow lakes located in Drawieński National Park. Oceanological and Hydrobiological Studies 38(3), 69-76.

21. Pei Sun Loh, Molot L.A., Nurnberg G.K., Watson S.B., Ginn B. 2013. Evaluating relationships between sediment chemistry and anoxic phosphorus and iron release across three different water bodies. Inland Waters 3, 105-118.

22. Psenner R., Boström B. Dinka M., Pettersson K., Pucsko R., Sager M. 1988. Fractionatio of phosphorus in suspended matter and sediment. Sediment phosphorus group: Working group summaries and proposals for future research. Arch. Hydrobiol. Beih. Ergebn. Limnol, 30, 98-110.

23. Søndergaard M., Jensen P.J., Jeppesen E. 2001. Retention and internal loading of phosphorus in shallow, eutrophic lakes. Scientific World Journal, 23(1),427-442.

24. Vollenweider RA (1968). Scientific fundamentals of the eutrophication of lakes and flowing waters. OECD. Paris. 